\title{
Relationship of Consumer Happiness \& Outcomes: The Mediating Role of Gratitude (A Case of Apparel Industry)
}

\author{
SAYYED ADNAN SHABBIR \\ $\mathrm{PhD}$ Scholar, Faculty of Management Sciences, \\ International Islamic University, Islamabad, Pakistan. \\ E-mail: $\underline{\text { adnan.fms@ iiu.edu.pk }}$ \\ Dr. FAUZIA SYED \\ Assistant Professor, Faculty of Management Sciences, \\ International Islamic University, Islamabad, Pakistan. \\ E-mail: fauzia.syed@iiu.edu.pk
}

\begin{abstract}
Positive emotions have drawn considerable interest of researchers in the recent past. One such emotion is happiness. The current study attempts to discover the underlying mechanism through which consumer happiness transforms into positive outcomes. Based on the "broaden and build theory of positive emotions" a model was developed and tested. Gratitude has been taken as a mediating variable. The proposed model explains the Pakistani customers' shopping considerations from well known clothing outlets. Consumer happiness in this study has been used as an antecedent of repurchase intentions and customer advocacy, whereas, gratitude mediates the relationship between consumer happiness and positive outcomes. Data was collected with the help of structured questionnaire from 330 respondents through survey method. All questionnaires were personally administered. PLS-SEM techniques have been used through smart PLS 3 for testing the model. The relationship between consumer happiness and customer advocacy was found significant. Gratitude was found as a significant mediator among consumer happiness and outcomes. However, repurchase intention from branded clothing stores in Pakistan was found to be insignificantly affected by consumer happiness. The study contributes towards the better comprehension about the shopping experience of Pakistani shoppers towards branded clothing stores in true letter and spirit. The study contributes to the existing body of literature by incorporating experiences of shoppers from emerging economies like Pakistan and establishing the mechanism through which consumer happiness transforms consumer experiences into positive outcomes.
\end{abstract}

Keywords: Consumer Happiness, Gratitude, Repurchase Intention, Customer Advocacy.

\section{Introduction}

Since the introduction of marketing concept in 1950s and subsequent technological advances, have given companies many tools to identify and respond to the demand of their potential customers (Patra, Mukhopadhyay, \& Dash, 2020). The building of networks over a period of time also translates into long term relationship with customers and may produce a stream of happy customers (Belen \& Yıldırım, 2020).

Research suggests that emotions and behavioral intentions such as loyalty, recommendation, and willingness to pay more are interlinked (Chan et al., 2015; Jani \& Han, 2015; Menninghaus et al., 2015). Emotions are considered to be one of the most valuable predictors of consumer behavior (Gaur et al., 2019). Similar views are also expressed by Lerner et al., (2015) who believe that emotions 'powerfully, 
predictably, and pervasively influence decision making'. Hence, it could be inferred that emotions can influence customer outcomes in any setting (Rychalski \& Hudson, 2017).

The role of emotions in customer loyalty is a significant stream of research believes (Collier \& Barnes, 2015). Brands play an important role in developing customer relationships which ultimately has an impact on the business performances. This involvement of the consumer with the brand leads to loyalty (Lastner et al., 2016). According to Yacobi (2015), happiness is central to the reason for the existence of human life. Happiness research has received some attention from psychologists and economists, particularly in exploring the relationship between happiness and economic/ social factors (Leerattanakorn \& Wiboonpongse, 2017).

Almost two decades of research suggest that individuals can increase their well-being by engaging in socalled positive activities (Lyubomirsky \& Fritz, 2018). This suggests that theoretically happiness is touched several times to argue that it produces well-being and other positives in life generally as well as specifically; yet marketing literature on how and why happiness results in favorable outcomes is not fully understood (Walsh et al., 2018). In addition, the literature demonstrates that happiness and pro-social behavior are interlinked which may form a positive feedback loop and create upward spirals. This positive stream of literature however omitted the consumer happiness perspective and its beneficial outcomes in the marketing context specifically in terms of emerging brands (Chancellor et al., 2017; Layous et al., 2017). Thus, the current study is aimed at looking into this overlooked stream of research and proposes consumer happiness at the base of other favorable processes to produce advocacy and repurchases in consumers.

\section{Literature Review}

This study employs broaden and build theory in order to comprehend the engagement of customers with established apparel brands of Pakistan. Broaden-and-build theory proposed by Fredrickson (1998) set forths that emotions prepare humans, both physically and psychologically, to act in particular ways specifically for the ultimate formulation of behavior. Furthermore, positive emotions expand cognition and behavioral tendencies and enrich the potential behavioral opportunities. Thus in light of the above-stated narrations, consumer happiness is used as positive emotion by keeping in view the purpose of the study, and subsequently, repurchase intention and customer advocacy are designated as multiple potential behavioral outcomes. Moreover, as the basic objective of the study is to assess the mediating effect of gratitude on repurchase intention and customer advocacy during purchases made from established apparel stores, broaden-and-build theory of positive emotions, best explains that how and why consumer's emotions change the way they act.

\section{Consumer Happiness}

One positive emotion which has drawn attention of scholars and researchers in the recent past is happiness (Etkin, 2014). In the context of consumer research, happiness is defined as "a state of well-being and contentment; a pleasurable or satisfying experience" (Mogilner et al., 2012). An ever expanding body of literature establishes points out towards the correlation between happiness and positive outcomes. Furthermore, a meta-analysis of more than 200 studies involving 2,75,000 people worldwide reported that happiness is associated with success in multiple domains (Berkland et al., 2017). In addition, Research suggests that people who experience positive emotions such as happiness enjoy better outcomes (Walsh et al., 2018)

\section{Repurchase Intention}

Broaden-and-build theory of positive emotions (Fredrickson, 1998) explains the means through which positive emotions lead to positive outcomes like repurchase intention. The theory posits that "positive emotions broaden people's momentary though-action repertoires, widening the array of thoughts and 
actions that come to mind" (Fredrickson, 2004). Repurchase intention is a consideration to purchase more than once (Pramatatya (2015). According to Varga et al., (2014), it is the intention to often buy or utilize the product/service of a company in the future. Forecast about established apparel brands outlet by means of repurchase intention as intention basically aims that a certain decision will be made in near future (Patra $\&$ Gupta, 2020) and thus gives the significant justification to the authors for the incorporation of repurchase intention in the theoretical model.

\section{Customer Advocacy}

Highly influential communication by non-representatives of the company in which they defend the company from unnecessary critiques and support the company in terms of its promotion (Sashi, Brynildsen, $\&$ Bilgihan, 2019). The concept of customer advocacy has gained more prominence after the revolution in internet communication, specifically after the emergence of social media (Hollebeek \& Rather, 2019). The advocacy in true letter and spirit has altered the ways of promotion and communication like blogs, wikis, emails, and social networks (Harmeling et al., 2017). In order to yield some positive results by the companies via connecting and interacting, they need to apprehend and recognize the importance of advocacy in a mass gathering of individuals and organizations regardless of location (Hudson et al., 2016). In other words, advocacy usually made up of positive WOM information about a brand, identity, and or anything that becomes talk of the town Marketers at different point of time trying to influence by virtue of social media the customers without having a thorough look of customers at different stages as customers vary in terms of relational exchange and emotional bonds (Bilgihan et al., 2018) and thus provides the sound reason to authors to inculcate customer advocacy in research model in light of broaden and build theory.

\section{Consumer happiness and Re-purchase intention from emerging apparel brands}

In other words, fair and pleasant appraisals are the main causes of consumer happiness and the one who is giving the review or opinion must be having an altruistic approach as altruism is more associated with disinterested and selfless concern for the well-being of others (Mathwick \& Mosteller, 2017). The decision in terms of repurchase intention about shopping from established apparel brands partly depends upon consumer happiness (Ahmed et al., 2019). Since the basis of discussion of the study is to apprehend the underlying phenomenon for the building of repurchase intention for shopping from established apparel brands context, authors take into consideration the consumer happiness as an internal drive that induces an individual to conduct an online activity without further getting into the debate of egoistic review and or the altruistic review. A similar significant relation between consumer happiness and repurchase intention in the computer repair sector has also been revealed in the recent past study of Suetrong, Pires, and Chen (2018). From the above, it can be hypothesized that:

$\mathrm{H}_{1}$ : There is a positive relationship between consumer happiness and repurchase intention

\section{Consumer happiness and Re-purchase intention from established apparel brands}

A significant relationship between consumer happiness and advocacy intention had also been revealed in different recent studies but without considering apparel brand industry but to confirm the same relationship in other industries was also in their recommendation (Rai \& Nayak, 2018; Shimul \& Phau, 2018). Hence, the following hypothesis is anticipated on the basis of the above.

$\mathrm{H}_{2}$ : There is a positive relationship between consumer happiness and customer advocacy 
Gratitude from emerging apparel brand outlet as a Mediator in between Consumer happiness with emerging apparel brand store

Gratitude basically refers to a motivator for a variety of emotions, beliefs, and behaviors in relation to one particular entity, person, item, or event (Ma, Tunney, \& Ferguson, 2017). Gratitude is often the responses developed after practicing with the product and can have a direct effect on behavior (Dickens, 2017). In lieu to this, change in consumer behavior with respect to attitude towards mature and or luxury brands had significantly enriched the literature (Wang \& Sun, 2010) but definition over the period of time is now taking hold and indicates multiple connections between behaviors and gratitude (Malik \& Hadi, 2019; Zhu \& Kanjanamekanant, 2020; Malik, Hadi, Raza, Lodhi, \& Shabbir, 2020). The binding of skepticism and patronage intention was also revealed in a recent study of Amawate and Deb (2019) with the help of gratitude. Further, Chou and Chen (2018) showed that gratitude mediated the relationship between website quality and trust. This is similar to the findings of Malik and Hadi (2019) which also showed that attitude with gratitude mediated the relationship between usefulness and online purchases. Using the above-stated findings, this study puts forward the following hypotheses:

$\mathrm{H}_{3 \mathrm{a}}$ : Customer gratitude mediates the relationship between consumer happiness and repurchase intention $\mathrm{H}_{3 \mathrm{~b}}$ : Customer gratitude mediates the relationship between consumer happiness and customer advocacy

\section{Research Methodology}

Inference from the collected data was done with the help of the deductive approach. In order to quantify the data, a self-administered structured questionnaire was floated, and to approach the veracious sample size, among different viable available options, G Power was used. 90\% confidence interval with 5\% margin of error was used giving a sample size of 420 so, 420 questionnaires were floated, out of which 365 were received back giving a response rate of $87 \%$. Out of these, 25 questionnaires were discarded due to incomplete responses. Consequent of , 340 questionnaires were available for the purpose of analysis. Crosssectional data were collected using self-administered questionnaires from the customers who visit the new designers' outlet with the shopping intent and convenient sampling was used for the purpose of data collection.

For the purpose of measurement, the following instruments were used. Four item scale of happiness suggested by Boven \& Gilovich (2003) was used. Gratitude was measured with the help of an six-item scale developed by McCullough et al., (2002), whereas, four items of Tax et al., (1998) were used to measure repurchase intention. Moreover, customer advocacy was measured with three items scale suggested by Bendapudi and Berry's (1997. The questionnaire was adapted according to the requirements and dynamics of Pakistani culture.

Table 1: Summary of Instruments Used Variable

\begin{tabular}{|c|c|c|c|}
\hline Variable & Instrument Author & $\begin{array}{llr}\text { Reliability } & \text { of } & \text { the } \\
\text { instrument } & \text { in } & \text { past } \\
\text { studies } & & \end{array}$ & Number of Items \\
\hline Happiness & Boven \& Gilovich (2003) & $\alpha$ Reliability $=0.843$ & 4 \\
\hline Customer Gratitude & $\begin{array}{c}\text { McCullough et al., } \\
\text { (2002) }\end{array}$ & $\alpha$ Reliability $=0.909$ & 6 \\
\hline Customer Advocacy & $\begin{array}{c}\text { Bendapudi and Berry's } \\
\text { (1997) }\end{array}$ & $\alpha$ Reliability $=0.924$ & 3 \\
\hline Repurchase Intentions & Tax et al., (1998) & $\alpha$ Reliability $=0.728$ & 4 \\
\hline
\end{tabular}


The mediation effects between the IV's and DV's were evaluated using PLS 3.0 through structural equation modeling (SEM).

\section{Analysis}

\section{Convergent and discriminant validity tests}

Before running the mediation analysis, convergent and discriminant validity tests were run on the measurement model using PLS-SEM (Partial least Square Structural equation modelling) to validate that the association of indicators with endogenous variables. The results have been given in table 2 .

Table 2 Validity and Reliability analysis Standardized regression weighs for Consumer Happiness

\begin{tabular}{|c|c|c|c|}
\hline Items & Loadings & Composite Reliability & Average variance extracted \\
\hline Ch1 & 0.739 & & \\
\hline $\mathrm{Ch} 2$ & 0.806 & 0.843 & 0.532 \\
\hline Ch3 & 0.774 & & \\
\hline $\mathrm{Ch} 4$ & 0.768 & & \\
\hline \multicolumn{4}{|c|}{ Standardized regression weighs for Gratitude } \\
\hline Items & Loadings & Composite Reliability & Average variance extracted \\
\hline G1 & 0.875 & & \\
\hline G2 & 0.857 & & \\
\hline G3 & 0.837 & & \\
\hline G4 & 0.768 & 0.909 & 0.720 \\
\hline G5 & 0.775 & & 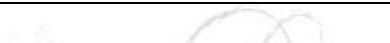 \\
\hline G6 & 0.787 & 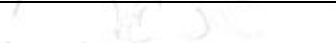 & 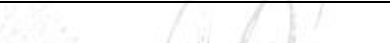 \\
\hline \multicolumn{4}{|c|}{ Standardized regression weighs for Repurchase Intention } \\
\hline Items & Loadings & Composite Reliability & Average variance extracted \\
\hline RI1 & 0.730 & & \\
\hline $\begin{array}{l}\text { RI2 } \\
\text { RI3 }\end{array}$ & $\begin{array}{l}0.801 \\
0.730\end{array}$ & 0.728 & 0.686 \\
\hline RI4 & 0.710 & & -1 \\
\hline \multicolumn{4}{|c|}{ Standardized regression weighs for Customer Advocacy } \\
\hline Items & Loadings & Composite Reliability & Average variance extracted \\
\hline Ad1 & 0.706 & & \\
\hline $\operatorname{Ad} 2$ & 0.749 & & \\
\hline $\operatorname{Ad} 3$ & 0.790 & 0.924 & 0.559 \\
\hline
\end{tabular}

Results in table 2 show that all the items loaded sufficiently on their respective endogenous variables. For factor loadings and composite reliability, $.7>$ is considered to be a good value. So all the items with loadings above .7 were used while items having loadings lower than .7 were dropped for all variables. Composite reliability (CR) was good for all the variables and Average variance extracted (AVE) cut-off value which is .5> was also met by all the variables.

\section{Discriminant Validity}

Table 3: Fornell \& Larcker Criterion

\begin{tabular}{|lllll|}
\hline & GRA & RINT & CA & CH \\
GRA & $\mathbf{0 . 7 6 2}^{*}$ & & & \\
RINT & 0.607 & $\mathbf{0 . 8 4 3} *$ & & \\
CA & 0.387 & 0.376 & $\mathbf{0 . 7 2 3}^{*}$ & \\
CH & 0.406 & 0.444 & 0.526 & $\mathbf{0 . 7 0 3}^{*}$ \\
\hline
\end{tabular}


Discriminant validity is defined as how much a variable is distinguished from other constructs (Hair at al., 2014). Cross loadings and Fornel larcker are the usual criterion used in order to assess the discriminant validity in PLS. The higher level of discriminant validity explains that the constructs are far different than other respective variables and phenomena is not going to be explained by them as proposed by Fornell and Larcker (1981). The square root of AVE of constructs is taken into account in order to ascertain the discriminant validity in the present study and thus by this, values of correlation among latent constructs are low then these values in order to prove discriminant legitimacy (Hwang \& Min, 2015). The values above 0.70 show the significant discriminant validity of the constructs.

\section{Mediation Analysis}

In the first phase of SEM analysis using PLS, I.V's and D.V's were added and direct impact was evaluated to understand I.V $\rightarrow$ D.V relationship.

Table 4: Results of direct effects

\begin{tabular}{|cccccc|}
\hline Path & $(\boldsymbol{\beta})$ & Sample Mean & Standard Deviation & T Statistics & P Values \\
$\mathrm{GRT} \rightarrow \mathrm{RINT}$ & 0.351 & 0.358 & 0.035 & 5.643 & 0.000 \\
$\mathrm{CH} \rightarrow \mathrm{GRT}$ & 0.028 & 0.024 & 0.041 & 0.568 & 0.544 \\
$\mathrm{CH} \rightarrow \mathrm{RINT}$ & 0.013 & 0.020 & 0.037 & 0.350 & 0.679 \\
$\mathrm{GRT} \rightarrow \mathrm{CA}$ & 0.137 & 0.140 & 0.061 & 2.247 & 0.025 \\
$\mathrm{CH} \rightarrow \mathrm{CA}$ & 0.154 & 0.146 & 0.033 & 2.545 & 0.022 \\
\end{tabular}

Results in table 4 show that $\mathrm{CH}$ had an insignificant impact on repurchase intention from emerging outlets of apparel stores $(\beta=0.013, \mathrm{p}=\mathrm{n} . \mathrm{s})$ consequent of which hypothesis 1 was rejected. Results also proved that $\mathrm{CH}$ had momentous blow on advocacy while making purchases from emerging outlet of garments $(\beta=$ $0.154, \mathrm{p}<0.05)$ which led to the acceptance of hypothesis 2 . After the evaluation of direct impact, indirect impact through mediator was evaluated and results for it are given in table 5.

Table 5: Indirect effects through mediator

\begin{tabular}{|clcccccc|}
\hline Hypothesis & PATHS & $(\beta)$ & $\begin{array}{c}\text { Sample } \\
\text { Mean }\end{array}$ & $\begin{array}{c}\text { Standard } \\
\text { Deviation }\end{array}$ & $\begin{array}{c}\text { T } \\
\text { Statistics }\end{array}$ & P Values & Decision \\
\hline $\mathrm{H}_{3 \mathrm{a}}$ & $\mathrm{CH} \rightarrow \mathrm{GRT} \rightarrow$ & 0.009 & 0.009 & 0.015 & 0.535 & 0.651 & $\begin{array}{c}\text { Not } \\
\mathrm{H}_{3 \mathrm{~b}}\end{array}$ \\
\hline $\mathrm{RINT}$ & $\mathrm{CH} \rightarrow \mathrm{GRT} \rightarrow \mathrm{CA}$ & 0.003 & 0.032 & 0.015 & 2.025 & 0.045 & $\begin{array}{c}\text { Supported } \\
\text { Supported }\end{array}$ \\
\hline
\end{tabular}

Table 5 shows results for indirect effects with gratitude as a mediator. Results show that gratitude did not mediate the relationship between $\mathrm{CH}$ and RINT $(\beta=.009, \mathrm{p}=\mathrm{n} . \mathrm{s})$. The $\mathrm{t}$ value was also below the acceptable value $(\mathrm{t}=0.535)$ which didn't provide support for hypothesis $3 \mathrm{a}$ as per which gratitude mediates $\mathrm{CH}-$ RINT relationship. Results also showed that gratitude mediated the relationship between $\mathrm{CH}$ and $\mathrm{CA}$ with $(\beta=.003, \mathrm{p}<0.05)$ values and $\mathrm{t}$ value was also significant $(\mathrm{t}=2.025)$ which provided support for hypothesis $3 \mathrm{~b}$ as per which gratitude mediates the relationship between $\mathrm{CH}$ and $\mathrm{CA}$. 

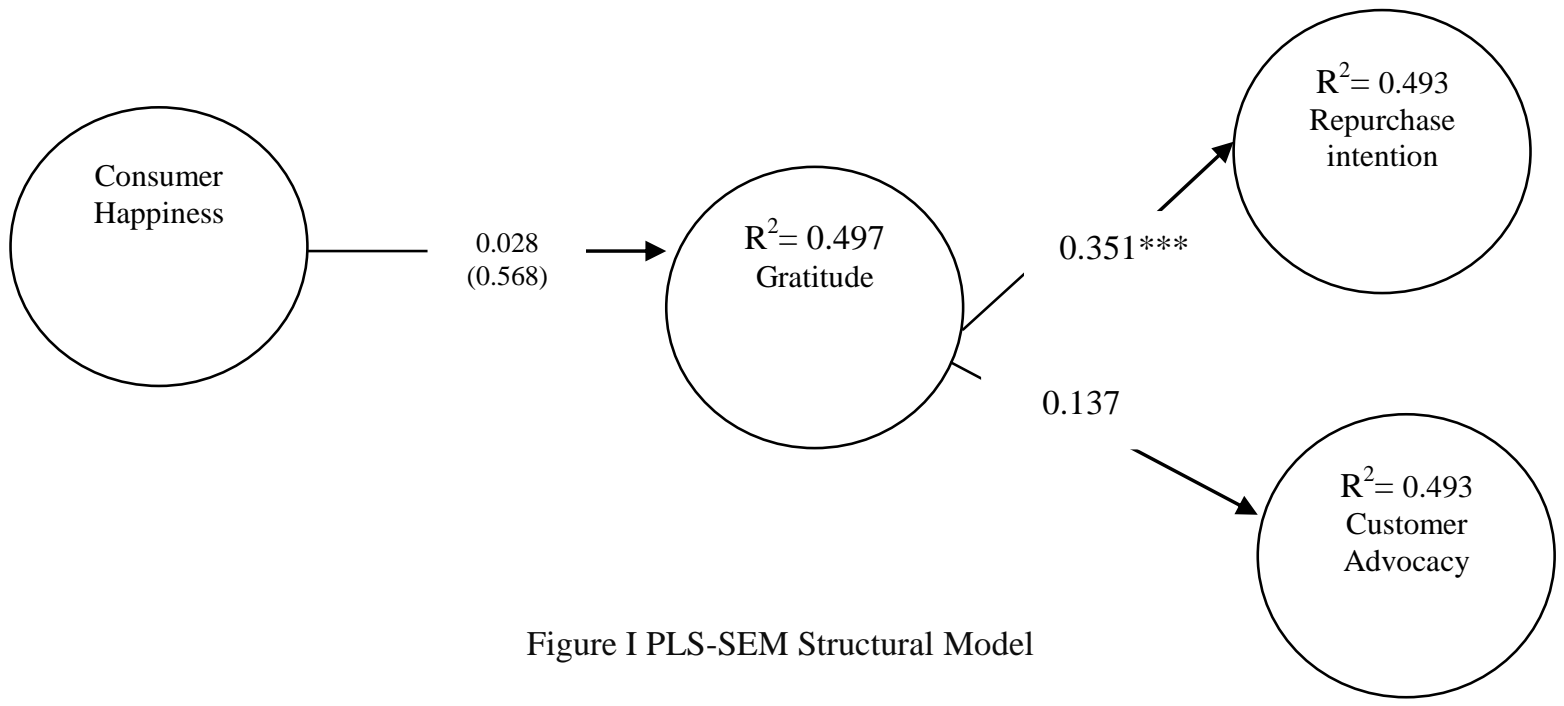

Figure I PLS-SEM Structural Model

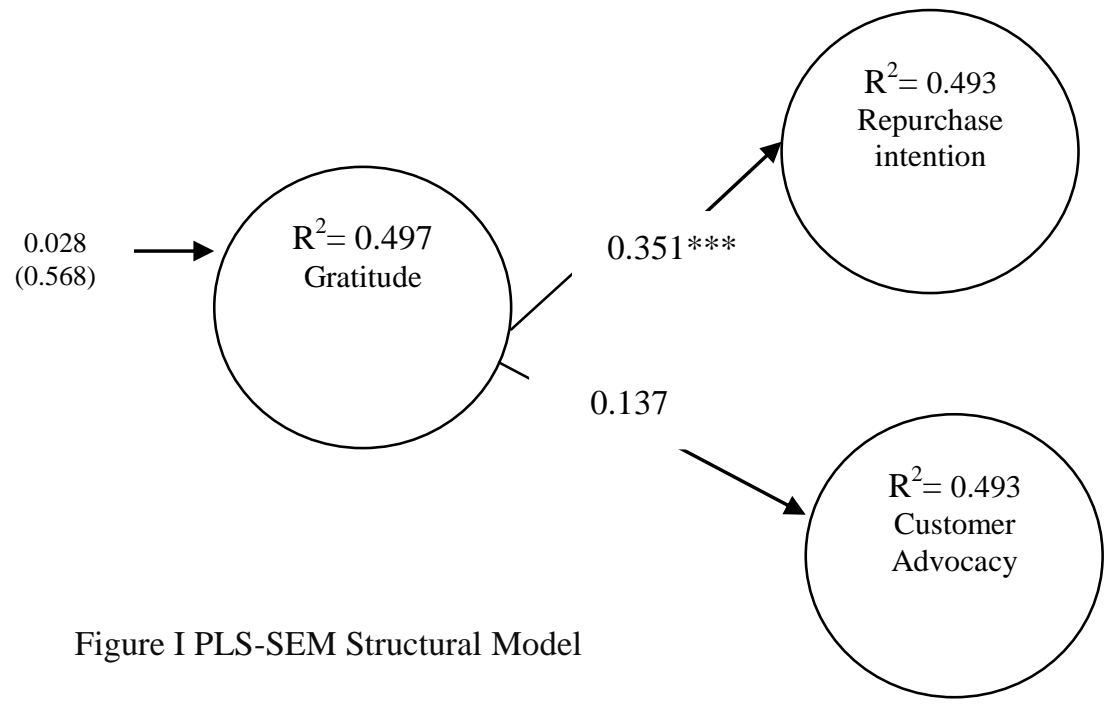

Note: ***Significant at .001 level (two tailed), **significant at .01 level (two tailed) and *significant at .05 level (two tailed)

\section{Discussion}

Results of the study reveal that customer happiness from emerging apparel store brands does not affect repurchase intention. Making the domestic apparel industry as a brand is still in its sprouting phase and in it specifically, the reliance by the customers on the initiative taken by young entrepreneurs is still in its infancy time and people are not motivated enough to repurchase from the specific XYZ brand, however, accidentally repeat make take place and is not the topic of discussion. Moreover, due to lack of checks and balances because of the shortage of infrastructure both in terms of finances and expertise, there is the probability of error and it is difficult to rely heavily on a single outlet though the previous experience was up to the mark. This result is similar and consistent with a previous study on the restaurant industry conducted by Chaouali et al., (2019).

Research also revealed consumer happiness with the emerging apparel brands had a significant impact on consumer advocacy for that specific emerging XYZ brand. Individuals behold of the belief that consumer happiness is the key for long-lasting relationships and it can help in intriguing the customers to boost their advocacy trend by putting the lives of others both of customers and emerging brand outlet owner at ease without any greed. Results also revealed that the ease with which information can be ingress on online platforms does influence the intent of individuals to use it while making e-purchases. Customers are more inclined towards the simple information sourced from the common man instead of company representatives by giving high weightage. Bilro et al., (2019) and Hsieh et al., (2018) also revealed similar results.

The impact of gratitude towards eWOM was evaluated as a mediator in the next part of the study. Results revealed that gratitude mediates only the relationship of customer happiness and the outcome variable i.e., consumer advocacy. This is in line with the findings of previous literature (Ni, Yang, Zhang, \& Dong, 2015 ; Bryant, Osowski, \& Smith, 2020). Purchasing from emerging apparel brands and putting oneself at risk is purely because of emotions and feelings that predominantly affect the orientation of individuals towards the eventual intent of individuals. Gratitude in individuals inclined them to share information and this information is used in making final purchases from new entrants of the apparel industry. 


\section{Conclusions}

Entrepreneurs with the passage of time have entered variety of markets by taking diversified initiatives and facts indicate that their survival purely relies upon the information that prevails at the massive level in the market. Consumer advocacy makes it possible for entrepreneurs to let the people know and search for their desired product in less time during repurchase intention. Since consumer happiness plays such a vital role in advocacy by individuals, it is important that the spread of information should not only be exaggerated by spoiling the actual theme especially in the sectors of emerging online markets. Gratitude acts as a major actor in addition while shaping the customer advocacy for new entrants of the apparel industry.

The theoretical contribution of this paper is in extending broaden and build theory by examining the effect of consumer happiness on positive outcomes. The findings of this paper provides an understanding how consumer happiness can be translated into positive outcomes like customer advocacy and repurchase intentions. From the practical perspective, marketers should endeavor to make their customers happy which in turn would make them spread good words about the clothing stores they visit and buy from. Moreover, an important contribution of this study is the comprehensive theoretical model enriched with consumer happiness which basically councils that how the intervening role of gratitude impacts customer advocacy without bringing into consideration repurchase intention by boosting the trend of shopping from conveniently located outlets of the apparel industry.

\section{Contribution and Practical Implications}

This research demonstrates the role of consumer happiness by proposing a customer emotions and positive outcomes model. Barbosa (2017) believes that one of the many challenges for happiness research in marketing is to provide deeper understanding of consumer behavior. This study invites scholars to study positive emotions and resulting behaviors and help stores building edge over competition. The present research incorporates perspective of a developing economy like Pakistan and provides useful insights to the managers of clothing stores. It lends store owners and managers insights into customers positive emotions. In addition, this research lends managers understanding into how to develop marketing programs that will turn happy customers into repeat customers and eventually becoming advocates for particular clothing stores.

\section{Limitations and Future Research Directions}

There are some limitations to this study. Firstly, the present study is cross-sectional in nature because it was not possible to tap responses of same customers over different time intervals. Future studies should adopt a longitudinal design. Secondly, this study has tapped only apparel industry customers. It would be interesting to explore other industries as well, for example, hospitality industry. Thirdly, this study investigates one positive emotion, happiness. It would be interesting to explore other positive emotions and see their impact on positive outcomes.

\section{References}

Barbosa, B. (2017). Happiness in marketing. Entornos creativos, empleados felices: Una ventaja competitiva en la gestión empresarial y territorial, 75-90.

Belen, H., \& Yıldırım, M. (2020). Psychometric analysis of inflexibility of happiness in undergraduate students: A reliability and validity study. Journal of Positive School Psychology, 4(1), 69-78.

Berkland BEMA, Werneburg BLBA, Jenkins SMMS, Friend JLBS, Clark MMP, Rosedahl JKBS, Limburg PJMD, Riley BAMBA, Lecy DRBS, Sood AMD(2017) A worksite wellness intervention: improving happiness. Life satisfaction, and gratitude in health care workers Mayo Clin Proc Innov Qual Outcomes 1(3):203-210 
Bilgihan, A., Seo, S., \& Choi, J. (2018). Identifying restaurant satisfiers and dissatisfiers: Suggestions from online reviews. Journal of Hospitality Marketing \& Management, 27(5), 601-625.

Bryant, F. B., Osowski, K. A., \& Smith, J. L. (2020). Gratitude as a Mediator of the Effects of Savoring on Positive Adjustment to Aging. The International Journal of Aging and Human Development, 0091415020919999.

Chancellor, J., Margolis, S., Jacobs Bao, K., \& Lyubomirsky, S. (2018). Everyday prosociality in the workplace: The reinforcing benefits of giving, getting, and glimpsing. Emotion, 18(4), 507.

Chan, M., \& Singhal, A. (2015). Emotion matters: Implications for distracted driving. Safety science, 72, 302-309.

Chaouali, W., Lunardo, R., Yahia, I. B., Cyr, D., \& Triki, A. (2019). Design aesthetics as drivers of value in mobile banking: does customer happiness matter? International Journal of Bank Marketing.

Cheung, C. M., \& Lee, M. K. (2012). What drives consumers to spread electronic word of mouth in online consumer-opinion platforms. Decision support systems, 53(1), 218-225.

Chou, S., \& Chen, C. W. (2018). The influences of relational benefits on repurchase intention in service contexts: the roles of gratitude, trust and commitment. Journal of Business \& Industrial Marketing.

Collier, J. E., \& Barnes, D. C. (2015). Self-service delight: Exploring the hedonic aspects of selfservice. Journal of Business Research, 68(5), 986-993.

Dean, J. K. (2009). Quantifying social justice advocacy competency: Development of the social justice advocacy scale.

Deb, M., \& Amawate, V. (2019). Extending the knowledge on cause-related marketing (CrM) campaign with focus on skepticism. VINE Journal of Information and Knowledge Management Systems.

Duan, J., \& Dholakia, R. R. (2017). Posting purchases on social media increases happiness: The mediating roles of purchases' impact on self and interpersonal relationships. Journal of Consumer Marketing, 34(5), 404-413. HYPERLINK "https://psycnet.apa.org/doi/10.1108/JCM-07-2016-1871" It "_blank" https://doi.org/10.1108/JCM-07-2016-1871

Jordan Etkin (2014) ,"Choosing Variety For Shared Consumption", in NA - Advances in Consumer Research Volume 42, eds. June Cotte and Stacy Wood, Duluth, MN : Association for Consumer Research, Pages: 47-52

Fredrickson, B. L. (1998). What good are positive emotions?. Review of general psychology, 2(3), 300-319.

Fritz, M. M., \& Lyubomirsky, S. (2018). Whither happiness? When, how, and why might positive activities undermine well-being. The social psychology of living well, 101-115.

Gaur, J., Mani, V., Banerjee, P., Amini, M., \& Gupta, R. (2019). Towards building circular economy: A cross-cultural study of consumers' purchase intentions for reconstructed products. Management Decision.

Ha, J., \& Jang, S. S. (2012). The effects of dining atmospherics on behavioral intentions through quality perception. Journal of Services Marketing.

Hair Jr, J. F., Sarstedt, M., Hopkins, L., \& Kuppelwieser, V. G. (2014). Partial least squares structural equation modeling (PLS-SEM): An emerging tool in business research. European business review.

Harmeling, C. M., Moffett, J. W., Arnold, M. J., \& Carlson, B. D. (2017). Toward a theory of customer engagement marketing. Journal of the Academy of marketing science, 45(3), 312-335.

Hollebeek, L., \& Rather, R. A. (2019). Service innovativeness and tourism customer outcomes. International Journal of Contemporary Hospitality Management.

Jani, D., \& Han, H. (2015). Influence of environmental stimuli on hotel customer emotional loyalty response: Testing the moderating effect of the big five personality factors. International Journal of Hospitality Management, 44, 48-57.

Jeong, E., \& Jang, S. S. (2011). Restaurant experiences triggering positive electronic word-of-mouth (eWOM) motivations. International Journal of Hospitality Management, 30(2), 356-366.

Jordan, D. G., Collins, A. C., Dunaway, M. G., Kilgore, J., \& Winer, E. S. (2020). (2020). Negative affect interference and fear of happiness are independently associated with depressive symptoms. Journal of Clinical Psychology.

Lastner, M. M., Folse, J. A. G., Mangus, S. M., \& Fennell, P. (2016). The road to recovery: Overcoming service failures through positive emotions. Journal of Business Research, 69(10), 4278-4286. 
Layous, K., Nelson, S. K., Kurtz, J. L., \& Lyubomirsky, S. (2017). What triggers prosocial effort? A positive feedback loop between positive activities, kindness, and well-being. The Journal of Positive Psychology, 12(4), 385-398.

Leerattanakorn, N., \& Wiboonpongse, A. (2017). Happiness and Community-Specific Factors. Applied Economics Journal, 24(2).

Lerner, J. S., Li, Y., Valdesolo, P., \& Kassam, K. S. (2015). Emotion and decision making. Annual review of psychology, 66.

Lyubomirsky, S., \& Lepper, H. S. (1999). A measure of subjective happiness: Preliminary reliability and construct validation. Social indicators research, 46(2), 137-155.

Ma, L. K., Tunney, R. J., \& Ferguson, E. (2017). Does gratitude enhance prosociality?: A meta-analytic review. Psychological Bulletin, 143(6), 601.

Malik, I. A., \& Hadi, N. U. (2019). Inspirational factors of electronic word of mouth: A case of social networking sites. Journal of Managerial Sciences, 13(2).

Malik, I. A., Hadi, N. U., Raza, M. A., Lodhi, D. R., \& Shabbir, S. A. (2020). Apprehending Inspirational Persuasion Factors for Intention to use eWOM by Highlighting Mediation of Attitude towards eWOM: A Case of Social Network Sites. Pacific Business Review International, 13(4), 83-98.

Mathwick, C., \& Mosteller, J. (2017). Online reviewer engagement: A typology based on reviewer motivations. Journal of Service Research, 20(2), 204-218.

C Mogilner, J Aaker, SD Kamvar, (2012). How happiness affects choice. Journal of Consumer Research 39 (2), 429-443

Patra, D. G., \& Gupta, P. Y. (2020). Determinants of Digital Payment Services and Behavioral Loyalty among Generation Y. Pacific Business Review International, 13(4).

Patra, D. G., Mukhopadhyay, I., \& Dash, D. C. (2020). Employer Branding: A Perspective of Practicing HR Professionals in. Pacific Business Review International, 13(4).

Rai, S., \& Nayak, J. K. (2018). Role of event personality and exhibitors' eudaimonic and hedonic happiness in predicting event advocacy intentions. International Journal of Event and Festival Management.

Rychalski, A., \& Hudson, S. (2017). Asymmetric effects of customer emotions on satisfaction and loyalty in a utilitarian service context. Journal of Business Research, 84-91.

Sashi, C. M., Brynildsen, G., \& Bilgihan, A. (2019). Social media, customer engagement and advocacy. International Journal of Contemporary Hospitality Management.

Schellong, M., Kraiczy, N. D., Malär, L., \& Hack, A. (2019). Family firm brands, perceptions of doing good, and consumer happiness. Entrepreneurship theory and practice, 43(5), 921-946.

Shimul, A. S., \& Phau, I. (2018). Consumer advocacy for luxury brands. Australasian Marketing Journal (AMJ), 26(3), 264-271.

Suetrong, P., Pires, G. D., \& Chen, T. (2018). Conceptualising the effect of brand love on consumers' repurchase intentions for consumer products. Global Business and Economics Review, 20(2), 213-230.

Varga, A., Dlacic, J., \& Vujicic, M. (2014). Repurchase intentions in a retail store - exploring the impact of colours. Journal of Econviews, 27(2), 229-224.

Walsh, L. C., Boehm, J. K., \& Lyubomirsky, S. (2018). Does happiness promote career success? Revisiting the evidence. Journal of Career Assessment, 26(2), 199-219.

Wang, H., \& Sun, L. (2010). Trust-involved access control in collaborative open social networks. In 2010 Fourth International Conference on Network and System Security (pp. 239-246). IEEE.

Wood, A. M., Joseph, S., Lloyd, J., \& Atkins, S. (2009). Gratitude influences sleep through the mechanism of pre-sleep cognitions. Journal of psychosomatic research, 66(1), 43-48.

Yacobi Ben, G. (2015). Life and the Pursuit of Happiness. Journal of Philosophy of Life, 5 (2), 82-90.

Zhu, Y. Q., \& Kanjanamekanant, K. (2020). No trespassing: exploring privacy boundaries in personalized advertisement and its effects on ad attitude and purchase intentions on social media. . Information \& Management, , 103314. 